\title{
Professionhood and professionalism as an educational aid for facilitating nursing students' development and renewal of self and profession
}

\author{
Rosalina F. Chiovitti * \\ Collaborative Bachelor of Nursing Program, School of Health Sciences, University of New Brunswick-Humber College Institute \\ of Technology \& Advanced Learning, Toronto, Ontario, Canada
}

Received: June 11, 2015

Accepted: July 28, 2015

Online Published: August 17, 2015

DOI: $10.5430 /$ jnep.v5n11p51

URL: http://dx.doi.org/10.5430/jnep.v5n11p51

\begin{abstract}
Educational aids that replicate life-long learning and facilitate professional nursing identity development are important to the education and practice of nursing students. The on-going development and renewal of self and the nursing profession need to exist together, each informing the other. Reflecting on examples from an introductory course on nursing as a profession with first year baccalaureate nursing students in Canada, the aim is to discuss how Margretta Styles' ideas of professionhood and professionalism were used to engage students in course content and process. The data source for this article is a description of an educational practice derived from Styles ideas of professionhood and professionalism. Guided by a constructivist interpretative-qualitative educational perspective, the cyclic interplay between Styles ideas is offered as an educational aid for facilitating students' awareness of self (professionhood) and what is expected by the nursing profession (professionalism); and, as a tool for students and educators to continue to imagine and re-imagine their professional nursing identity individually and as a group.
\end{abstract}

Key Words: Professional identity development, Nursing education, Professionalism, Students, Professionhood, Nursing organizations

\section{INTRODUCTION}

The development and renewal of self and the nursing profession can be located within the literature directed at making visible the foci of nursing, what caring is, how caring occurs from nurses' perspectives, ${ }^{[1-5]}$ and through evidenceinformed nursing practice. ${ }^{[6-9]}$ However, the delineation of professional nursing and its contribution to interdisciplinary health care, needs to begin with nursing students' professional identity development by understanding self (professionhood) and what is required of nurses by the nursing profession (professionalism). The development and renewal of self and the nursing profession need to exist together, each informing the other. This idea is consistent with Lemire Rodger's (p.134) ${ }^{[10]}$ paradoxical observation. She states that on the one hand "each individual professional cannot speak on behalf of his or her profession unless mandated by the collective to represent the profession". (p.134) ${ }^{[10]}$ On the other hand, she asserts that individual nurses do represent and speak on behalf of the nursing profession everyday through their actions, inactions, and interactions with the public. Lemire Rodger ${ }^{[10]}$ explains that the behaviours of each nurse "reflects on nursing profession as a whole and

\footnotetext{
${ }^{*}$ Correspondence: Rosalina F. Chiovitti; Email: rosalina.chiovitti@sympatico.ca; Address: School of Health Sciences, Humber College Institute of Technology \& Advanced Learning, Toronto, Ontario M9W 5L7, Canada.
} 
contributes to the public image of a profession"(p.134). It is for this reason that not only do nursing students need to know what is required of them as a member of the nursing profession (professionalism), it is also necessary for them to have a sense of their own individual characteristics and evolving definition of nursing (professionhood).

\section{AIM AND APPROACH}

Using educational aids to replicate the process of on-going development and renewal of self and profession with nursing students is important to supporting the education and practice of nursing students. Margretta Styles' ${ }^{[3]}$ ideas of professionhood and professionalism were used as an educational aid to develop baccalaureate nursing students' views of being a professional by engaging them in the development and renewal of self and profession. The aim is to discuss how nursing students in a first year, first semester introductory 13 week course on nursing as profession were invited to participate in a cyclic interplay between professionhood and professionalism to facilitate nursing students' professional identity development. This introductory three credit, three hours per week classroom course on nursing as a profession is a precursor to skills lab, simulations, and clinical field placements that students will engage in over the duration of the four year baccalaureate program.
In the first and second sections of this paper, Margretta Styles' ${ }^{\text {[3] }}$ ideas of professionhood and professionalism are described. In the third section, the cyclic interplay between these ideas is described in context of a constructivist interpretative-qualitative educational perspective. Specifically, how the cyclic interplay between professionhood and professionalism was used to engage students in course content and process in a manner that replicates life-long learning and embraces the development and renewal of self and profession.

\section{Conceptualization}

\subsection{Professionhood defined}

The word professionhood is not found in the English dictionary. Styles ${ }^{[3]}$ defines professionhood as "the characteristics of the individual as a member of a profession"(p.8). It includes what the nurse is passionate about and their evolving definition of professional nursing. Students are invited to consider their evolving sense of self and their evolving definition of professional nursing in context of each weekly theme; and, in relationship to students' understanding of what is expected of them by nursing organizations. Examples of weekly course themes are listed in Figure 1. Accountability and self-regulation are important dimensions of professionhood and are addressed in the next two subsections.

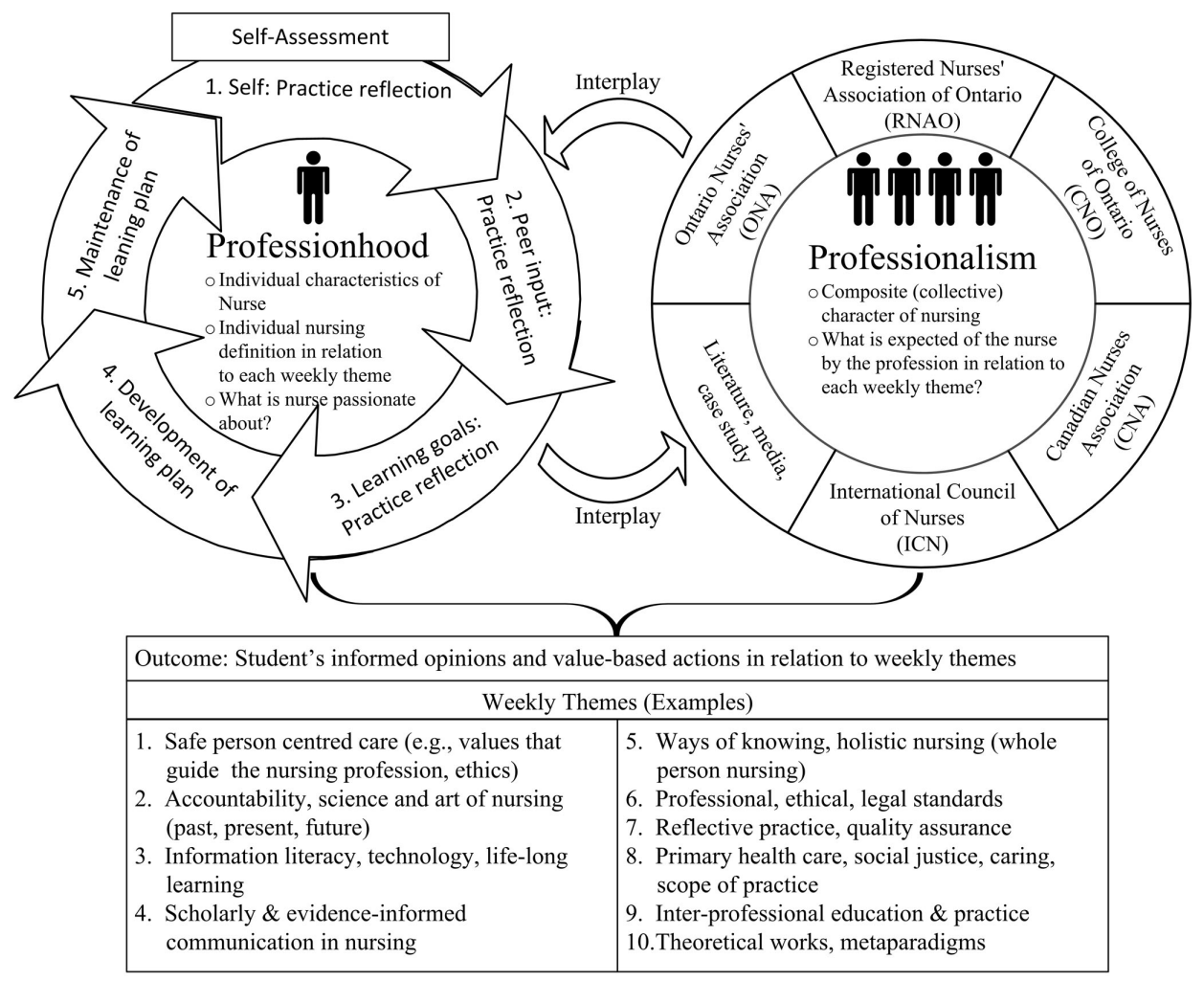

Figure 1. A pictorial depiction of facilitating students' cyclic interplay between professionhood and professionalism 


\subsection{Professionhood and accountability}

According to Styles, ${ }^{[3]}$ professionhood pertains to the individual nurse, promotes active participation, and calls forth the nurses' individual accountability in their practice. Accountability is a core dimension of professional nursing practice in which students as future nurses prepare to be responsible for their own "judgments, actions and omissions as they relate to life-long learning". (p.26) ${ }^{[11]}$ Samuel and Chiche (p.xvi) ${ }^{[12]}$ define personal accountability as "doing what you say you are going to do" and professional accountability is described as "being answerable" for nursing practice. $(\mathrm{p} .82,83)^{[13]} \mathrm{It}$ is acknowledged that there are more dimensions to accountability, however these brief glimpses were provided to show that both personal and professional accountability call forth active participation from nursing students as future nurses. Madden-Styles ${ }^{[4]}$ explains that the power to act or do comes from nurses having a sense of what they are about, which is communicated as individuals and as a group. Also, Styles ${ }^{[3]}$ states that without professionhood there is high risk for passivism, lack of action, and for individual nurses not to think critically about practice.

While nurses are unified in their actions, professional nurses are not robots and do not follow mandates blindly. For example, according to the College of Nurses of Ontario (CNO) (p.1) ${ }^{[14]}$ “.... nurses and employers play an important role in ensuring that the documents [nursing practice standards and practice guidelines] are up-to-date and relevant to current nursing practice environments". $\mathrm{CNO}^{[14]}$ "consults extensively with nurses in a variety of practice settings before writing or revising a practice standard or guideline"(p.1). Nurses' constant monitoring of self and profession requires nursing students to develop a solid sense of their own individual characteristics and their definitions of nursing (professionhood) in preparation for their careers as Registered Nurses. Professionhood involves reflecting on questions, such as: 1) what is my evolving definition of professional nursing? 2) are my actions, lack of actions, and interactions with the public consistent with nursing practice standards, practice guidelines, and best practice guidelines? and 3) how can I contribute to the development and renewal of the nursing profession and self, based on my passion, experiences, abilities, knowledge, strengths, credentials, and education ? $^{[3]}$

\subsection{Professionhood and self-regulation}

In Canada, according to the Canadian Nurses Association (CNA), "Canadians have given the nursing profession the privilege of self-regulation... [and require nurses to] engage in self-regulation collectively as a profession and as individuals". (p.8) ${ }^{[15]}$ Self-regulation "is the ability of a profession to predominantly control its own

Published by Sciedu Press admission standards... requirements, [and] norms for its practice". (p.96) ${ }^{[16]}$ In self-regulation the nursing profession governs itself through the provincial or territorial regulatory body. The provincial regulatory body in Ontario Canada is the College of Nurses of Ontario (CNO). ${ }^{[17]}$ While the CNO's mandate is to protect the public, it does this by supporting nurses to provide quality care through practice standards and guidelines that nurses agreed to abide by. One interpretation of this is that all nurses know at all times the CNO practice standards and guidelines that: 1) guide the contract made with society about what the public can expect when receiving services from Registered Nurses; 2) are used to judge nurses' practice with persons; and 3) serve as a reference point for the nurses' continued development, enhancement, and renewal as part of self-regulation.

Self-regulation includes nurses' understanding the mandates of the regulatory body, professional association, and union; practicing according to relevant legislation, nursing practice standards and guidelines; keeping current, maintaining their competency and fitness to practice. ${ }^{[17]}$ The International Council of Nurses (ICN) ${ }^{[18]}$ states "nurses need to be major participants in the planning and direction of nursing education, nursing services, regulatory bodies and other health related activities"(p.2). Developing a sense of self and profession is important to how nurses, individually and as a group, engage in the revision and development of new nursing standards and practice guidelines when values, conditions, and needs in practice change. For instance, in Ontario Canada, nurses recently participated in the revision of the practice standard for medication administration. ${ }^{[19]}$

Scholars in practice, ${ }^{[21,22]}$ education, ${ }^{[23-26]}$ and leadership ${ }^{[27]}$ note the importance of reflection, life-long-learning, and improvement. Facilitating students' abilities to integrate new information, insights, experiences, and existing professional knowledge is important for students' professional identity development ${ }^{[28,29]}$ and self-regulated learning. ${ }^{[30]}$ Similar to self- regulatory activities in nursing practice, self-regulated learning in education is active in nature. In self- regulated learning, "learners activate their learning goals". (p.28) ${ }^{[30]}$ This is part of their accountability for life-long learning as future nurses. ${ }^{[20,31]}$

In Ontario Canada, the self-assessment component of CNO's ${ }^{[20]}$ quality assurance program is one of the selfregulatory activities that all nurses are expected to complete. One component of the quality assurance program is selfassessment. Nurses reflect on their individual characteristics and competencies. As shown in the professionhood section of Figure 1, CNO's self-assessment is accomplished 
through self-practice reflection which includes peer input for the development of learning goals based on their identified strengths and areas for development. Nurses then develop and maintain a learning plan to meet their learning goals.

Each learning goal is an opportunity for development and renewal of nurses as they work toward enhancing their strengths and/or addressing their areas for improvement. Practice reflection and peer input aspects of self-assessment create "aha" reactions for nursing students. An "aha reaction" is a "sudden realization or inspiration, experienced usually during creative thinking. . . experiences in which an individual utters 'aha' during a moment of revelation". (p.57) ${ }^{[32]}$ These "aha reactions" are valuable for the development and renewal of self and profession through nursing students' insights about their strengths and areas for development that they may, at first, overlook in classroom discussions, skills lab, field placements, and as future nurses. ${ }^{[20]}$

\subsection{Professionalism defined}

As shown in Figure 1, professionalism refers to "the composite [collective] character of the profession". (p.8) ${ }^{[3]}$ Moreover, according to the Registered Nurses' Association of Ontario (RNAO) best practice guideline, professionalism pertains to the "qualities or typical features of a profession or professional... a collection of attitudes and actions... knowledge and technical skill"'. (p.58) ${ }^{[33]}$ In addition, the Ontario Nurses' Association (ONA) states that active engagement in "continuous professional development is a hallmark of professional nursing practice". (p.20) ${ }^{[34]}$ In the dictionary, professionalism is further defined as "the skills or qualities required or expected of members of a profession...' (p.803) ${ }^{[35]}$ According to Styles, ${ }^{[3]}$ professionalism involves reflecting on questions such as: 1) what is the collective image of nursing as expressed by the nursing profession as a whole? and 2) how are my actions guided by what is required of nurses as expressed by nursing organizations?

\subsection{Professionalism and nursing organizations}

Madden-Styles ${ }^{[4]}$ argues that a nurse's evolving definition of professional nursing is a source of power for creating environments in which nurses individual and group efforts are unified. To facilitate reflection and learning about professionalism in nursing, students were invited to consider what is expected of them by the nursing profession as expressed by nursing organizations and the literature. In Canada, these expectations are expressed by nursing organizations internationally by the ICN, nationally by the CNA, and provincially in Ontario through CNO (regulatory body), RNAO (professional body), and ONA (union body).
As shown in the professionalism section of Figure 1, it is acknowledged that literature, media, and a case study that unfolds over the duration of the course were used to help students' imagine clinical practice ${ }^{[36]}$ as they developed their evolving definition of professional nursing in context of the salient features of what is expected by the collective of the nursing profession. However, for the purpose of this paper, only nursing organizations will be used to represent the collective of the nursing profession. One of the reasons for this is because documents from nursing organizations are developed in context of evidenced-based literature, which includes theoretical literature and case scenarios. For example, the $\mathrm{CNO}^{[37]}$ states that the practice standard on infection prevention and control is "evidence-based and outlines practice expectations for all nurses in all roles and practice settings" (p.3). In addition, case scenarios from hospital, long-term care, and community settings with patients, residents, and clients are further included in the $\mathrm{CNO}^{[37]}$ practice standard on infection prevention and control. Similarly $\mathrm{CNO}^{[38]}$ practice standard on professional standards specifies that nurses need to ensure that "practice is based on theory and evidence" (p.8), further supporting the importance of developing an informed evolving definition of nursing.

\subsection{Professionalism and regulatory diversity}

Styles ${ }^{[39]}$ states that regulatory systems vary from country to country (i.e., state governance of nursing versus selfgovernance of nursing or will have a combination of both). Styles ${ }^{[39]}$ explains that "regulation defines, set standards for, and legitimizes nursing as a profession... [and] that unity, commitment, strategic action and vigilance are required to shape regulation-whether through state governance or selfgovernance or both" (p.82). Challenges with "profession building" are documented in the literature internationally. $(\mathrm{p} .81,41)^{[39,40]}$ Profession-building pertains to the struggle of nursing to achieve professionalism. ${ }^{[39,40]}$ Regardless of the system of regulation in place in a country, Styles ${ }^{[9]}$ states it is necessary to understand what guides the professionalism of nursing in their country. For continued development of self and profession, Styles ${ }^{[39]}$ asserts that nurses, and by association nursing students, need to reflect on questions such as:

What is the role of the professional association in regulation in your country? Does it serve as a regulatory body for nurses? ...to what degree is the profession self-governing and are nurses practicing independently? ... What is your plan of action [professionhood] to fully utilize regulation for profession-building purposes [professionalism]...? (p.82) 
3.7 Professionalism and its relationship to professionhood

Styles ${ }^{[3]}$ explains the relationship between professionhood and professionalism. Styles ${ }^{[3]}$ states the "professionalism of nursing will be achieved only through the professionhood of its members" (p.8). That is, professionalism of nursing students can only be achieved by developing their individual characteristics and professional identity. At the same time, Styles ${ }^{[3]}$ states that "professionhood is shaped within the larger context of professionalism"(p.8), in which students begin to recognize how societal expectations, literature, professional, ethical and legal standards influence their professional practice. It is in this way that professionhood and professionalism inform the other.

In developing professionhood and professionalism, students are invited to experiment and imagine their evolving definition of professional nursing in context of each weekly theme; and, in relationship to students' understanding of what is required of them by nursing organizations. Inviting students to engage in developing their professionhood and professionalism prompts learners “... to experiment and play around with ideas..." (p.1182) $)^{[21]}$ The cyclic interplay between professionhood and professionalism is shown in Figure 1. For example, nursing students were invited to personalize their individual characteristics and definition of professional nursing in accordance with ethical values of the nursing profession, as expressed by nursing organizations internationally, ${ }^{[41]}$ nationally ${ }^{[42]}$ and locally. ${ }^{[43-45]}$ These values that are associated with the professionalism of nursing are consistent with Canadian societal values of Medicare, person-centred services, primary health care, social justice, and caring: $;^{[46-48]}$ and, are reflected in the nurses' scope of practice ${ }^{[31]}$ For instance, in Ontario Canada, nurses' scope of practice is defined as: "the promotion of health and the assessment of, the provision of care for, and the treatment of health conditions by supportive, preventive, therapeutic, palliative, and rehabilitative means in order to attain or maintain optimal function". (p.3 $)^{[31]}$ This means that as a part of the professionalism of nursing, Registered Nurses, and by association nursing students, integrate not only the curative aspects of care but also health promotion, disease prevention, supportive, palliative and rehabilitative care; provide [holistic] assessment of "physical, emotional, spiritual, cognitive, developmental, environmental, social, and learning needs". (p.7) $)^{[31]}$

\section{Application}

4.1 Theoretical foundations for the application of professionhood and professionalism

Prior to discussing how Styles' ideas of professionhood and professionalism were facilitated with students, the cyclic na- ture of Styles' ideas in context of constructivist theoretical foundations in education is described. Although there are several views ${ }^{[24-26]}$ that exist within constructivism, common principles are that learners construct their own knowledge. Learners are provided with activities to encourage them to construct their own understanding of things in context of their own knowledge and experiences. Constructivist principles underpin the pedagogical design of the activity of inviting learners to actively construct their own knowledge through the back and forth process of reflecting on student's evolving definition of professional nursing (professionhood) and what is required of them by the nursing profession (professionalism).

Within a constructivist lens, the perspectives of persons are co-created, and negotiated through a continuous cycle of development and renewal. This cycle repeats for learners individually; and, collectively as part of a group or community of practice in which practices are shared within profession(s). ${ }^{[21,24-26,49-57]}$ As shown in Table 1 students are invited to participate in an in-class activity to connect to their own views of self and nursing profession. The activity is completed on paper or electronically. To facilitate a baseline of student's own views, on the first day of class for thirty minutes, before commencement of class discussions of course readings and themes, students are invited to think about what led them to choose nursing as a career. Student write about their passion when engaging in the activity of developing their evolving definition of professional nursing. Consistent with constructionist principles, students construct their evolving definition of professional nursing in a manner that is meaningful to them based on their prior knowledge and experiences. ${ }^{[21,24-26,49-57]}$ As students prepare to engage in class discussions, critical reflective questions (see Table 1) are provided to support students in writing about their own definition of professional nursing and how their views would guide their work with persons.

Within these "interpretative-qualitative or meaning" educational perspectives, (p.3;p.7 $)^{[55,58]}$ students are viewed as knowledgeable and as active in their learning. Guided by constructivists' principles, students' on-going construction is invited as they formulate, reformulate, and rejuvenate their "informed" evolving definition of professional nursing (see Table 2). Through individual reflection and class discussions, students track their thinking in terms of how they create, recreate, arrange, and rearrange their views in relation to what is required by the nursing profession (professionalism) and in context of specific case scenarios discussed in class. Students develop their "informed" opinions by supporting their views with weekly readings, resources, and examples. As further shown in Table 2, students name the theoretical 
idea that stood out for them from their course readings and resources. Following the worksheet in Table 2, students define their chosen theoretical idea and support their chosen theoretical idea by providing the citation used from course readings and resources. Students continue by providing examples showing the application of their chosen theoretical idea within learning scenarios and a case study that unfolds over the course. Students repeat the process for each new theoretical idea. In addition, students are encouraged to complete the worksheet in the order that best suits their own unique ways of learning. For instance, some students start with the examples from learning scenarios while others start with definition of a theoretical idea first. In this way, consistent with constructivist notions, students actively think through the application of course concepts; and, experiment with ideas in different directions, combinations and configurations. ${ }^{[21]}$ In accordance with constructivist views, students are invited to view theoretical ideas as "lenses" or "a pair of googles" that they put on and remove to actively create and recreate new knowledge in a manner that makes sense to them based on their previous knowledge and experiences. This is part of how students are engaged in their on-going development and renewal of self and profession.

Table 1. Example of week one in-class activity

Week One Activity:
Date:
Boundaries
- Activity is 30 minutes
Activity will include the entire class
Activity Guidelines
Before class discussions and readings, please begin to write about:
1) What is your definition* of professional nursing at this moment?
*Note. Definition "is the act or process of defining. A statement of the meaning of a word or the nature of a thing" (Canadian
Oxford Dictionary, 2006, p. 244)
What are some specific examples of how you imagine you will work with persons, based on your evolving definition of
professional nursing at this moment?
a) My values and beliefs related to being a professional nurse are?
b) My vision related to be being a professional nurse is? (i.e., What is the goal for my future practice as I imagine it?)
c) What is my mandate as a professional nurse? (i.e., what is my personal policy or course of action based on my prior knowledge
d) What main "issue" or concern in health care do I think requires advocacy?
e) What do I think the nursing profession requires of me?

What is your definition* of professional nursing at this moment? $\quad$ What are some specific examples of how you imagine you will work with persons?

\section{Rationale for Activity}

Becoming familiar with your informed evolving definition of professional nursing will help you articulate:

- What is important to you? (e.g., what are you passionate about? What individual characteristics are important to you?)

- What kind of nurse do you want to be with persons?

- What you think is required of you by the nursing profession? (e.g., individually and as part of nursing community).

Weekly, you will have the opportunity to further develop and celebrate your evolving definition of professional nursing based on your required course readings, resources, class discussions, and any new insights ("aha” moments). It is suggested that you maintain a separate sheet for each week of class to track your thinking, as you create and re-create your evolving definition of professional nursing based on what is important to you and what is required of you by the nursing profession. 
Table 2. Example of weekly in-class activity for connecting with self and profession

\begin{tabular}{|c|c|}
\hline \multicolumn{2}{|c|}{$\begin{array}{l}\text { Welcome to your weekly worksheet activity. Building on your evolving definition of professional nursing that you started in week } 1 \text {, } \\
\text { please add, delete, retain, or modify your definition based on one main theoretical idea that stood out for you in this week's readings } \\
\text { and resources. Each theoretical idea is considered for its possibilities for thinking, being, and acting as a professional nurse when } \\
\text { working with persons. By supporting your definition with specific citations from your course readings, you have the exciting } \\
\text { opportunity to develop an "informed" evolving definition of professional nursing based on what is important to you and what is } \\
\text { required of you by the nursing profession. } \\
\text { You are invited to think about each theoretical idea from course readings and resources as “lenses" or "goggles” that you put on and } \\
\text { remove to view your practice with the persons that we discuss in our course (e.g., case study). It is in this way that you can track your } \\
\text { thinking over each week as you create, recreate, articulate, organize, reorganize, and celebrate any new insights ("aha moments") for } \\
\text { your definition and corresponding professional practice. Happy Learning. } \\
\text { Reflective Question: } \\
\text { What one main theoretical idea stood out for you in this week's readings? }\end{array}$} \\
\hline \multicolumn{2}{|l|}{ Name/identify your chosen theoretical idea: } \\
\hline $\begin{array}{l}\text { Define or describe each aspect of the theoretical } \\
\text { idea based on your course readings and resources. }\end{array}$ & $\begin{array}{l}\text { Provide examples of how each aspect of theoretical idea guides you in working } \\
\text { with persons (e.g., case study)? }\end{array}$ \\
\hline \multicolumn{2}{|c|}{$\begin{array}{l}\text { Support your one chosen main theoretical idea by citing course reading. Please use American Psychological Association (APA) } \\
\text { format. }\end{array}$} \\
\hline
\end{tabular}

As shown in Figure 1, the cyclic interplay between professionhood and professionalism repeats in relation to each weekly theme in the course, creating opportunities for students' development and renewal of self and profession.

Students need on-going support to engage in internal and external reflection to enhance professional learning. ${ }^{[59,60]} \mathrm{A}$ travelling metaphor corresponds to how students were invited to reflect on the cyclic interplay between connecting to self (i.e., their individual definition of nursing or professionhood) and connecting with nursing organizations (i.e., what is expected of nurses as expressed by the nursing organizations or professionalism). In a travelling metaphor "education is seen as a journey... [and students are viewed as] a contributing partner in his [her] own learning"; and, as travellers that actively explore the subject matter of the course from different perspectives. (p.156) ${ }^{[50]}$ Within the travelling metaphor the educator and student peers are viewed as knowledgeable travel companions. ${ }^{[50]}$ As such, students locate themselves in terms of their individual professionhood while at the same time learn about requirements of the nursing profession (professionalism).

As shown in Figure 2, a generic template was developed that consists of critical reflective questions which are used to facilitate the cyclic interplay between professionhood, professionalism, and weekly themes. Consistent with Styles' ${ }^{\text {[3] }}$ ideas of professionhood and professionalism, exploration of professional practice issues is an individual and collective activity. As an individual activity, each week students in the course were invited to engage in a continual cycle that begins with an activity, called "connecting with yourself". As shown in the professionhood section of Figure 2, students considered ten critical reflective questions to assist them in 
developing their thinking and approaches from week to week. These ten critical reflective questions were designed to invite students to freely move back and forth between their ideas in their evolving definition of professional nursing. Table 1 shows how the first five questions (see Figure 2 - professionhood section) were introduced on the first day of class to help students articulate areas they are passionate about; individual characteristics that are important to them; and how these influence their views of working with persons. The weekly worksheet in Table 2 provides a glimpse of how the remaining five of the ten questions from professionhood section of Figure 2 were facilitated. Students tracked their thinking from one class to another using weekly worksheet shown in Table 2.
As a collective activity with student peers, students were invited to engage in "connecting with nursing organizations" (shown in the professionalism section of Figure 2). Students are asked to reflect on five main critical reflective questions. The essence of these five main critical reflective questions is for students to critically think about and celebrate their new insights or "aha reactions" (see Table 2 weekly worksheet). These questions assist students to reflect on what is expected of them by the nursing organizations and nurses' scope of practice. It is important to acknowledge that not all nursing organizations will address each weekly theme to the same degree and depend upon the primary mandates of the nursing organization.

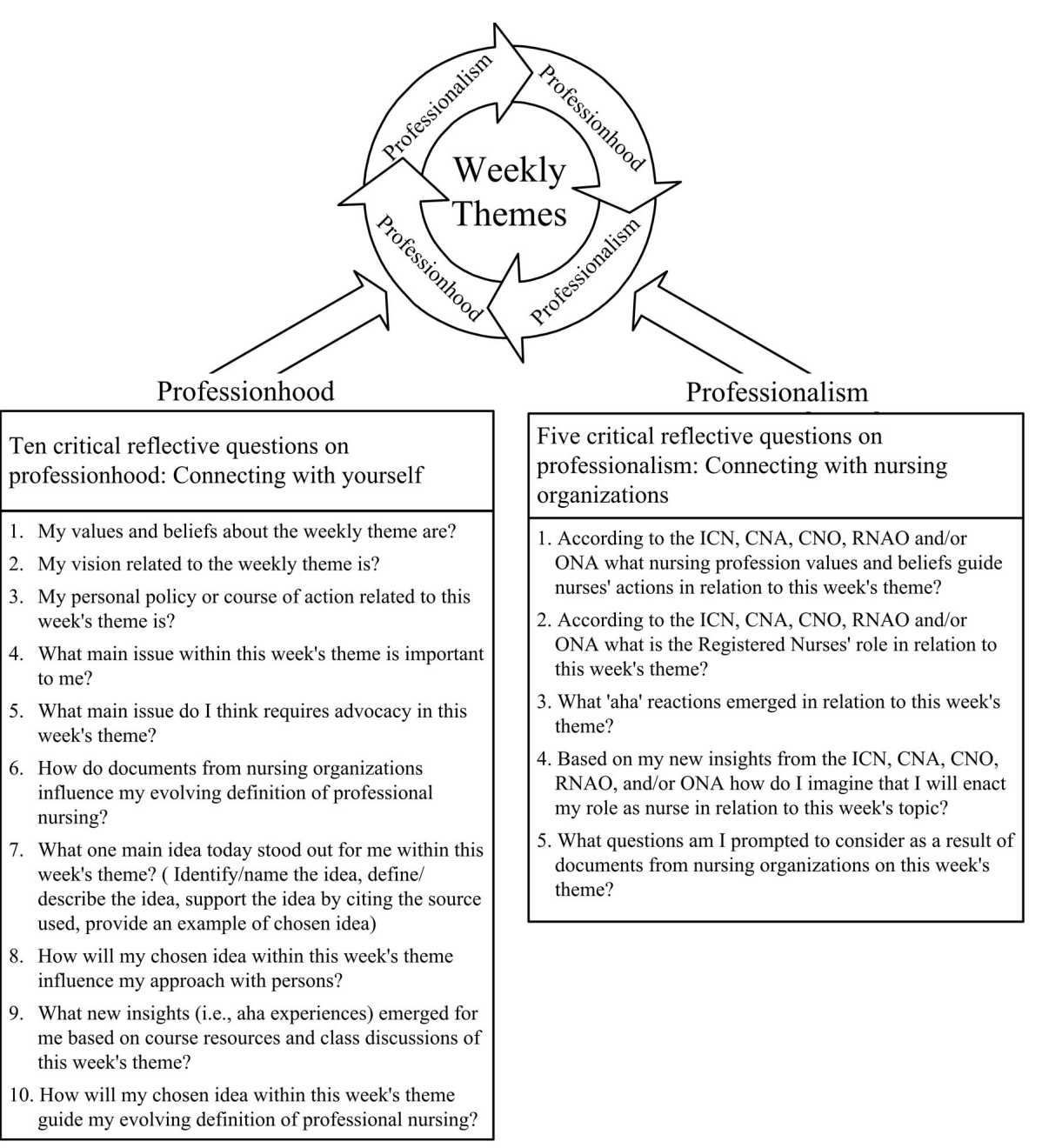

Figure 2. Generic template of critical reflective questions used to facilitate students' cyclic interplay between professionhood, professionalism, and weekly themes

\subsection{The significance of replicating life-long learning for development of self and profession}

Continuing with the educational perspective in which learners are conceptualized as evolving within an on-going cycle of development and renewal, nursing students were invited to consider how their individual characteristics (professionhood) were further developed and renewed. This was done based on what is required by the nursing profession in rela- 
tion to one of the weekly themes, such as the theme of "values and beliefs that guide the nursing profession in facilitating safe person-centred care" (see Figure 3). At the same time, students reflected on how their individual characteristics and passions within their evolving definition of nursing could be used to further assist with the development and renewal of the nursing profession as a whole as it relates to weekly course themes and learning. Through the cyclic interplay of professionhood and professionalism, students: 1) affirm or challenge what is important individually and collectively as part of the nursing profession; 2) discuss the need to sustain or change professional, ethical and legal standards and processes that are already in place; and 3) work on developing a sense of accountability for proposing and taking the lead in creating policies or processes where none exist. All relevant documents from nursing organizations are used to facilitate cyclic interplay between professionhood and professionalism in which students personalize their evolving definition of professional nursing in context of what is required of them by the nursing profession for the development and renewal of self.

Students' awareness and knowledge of self and profession is an important stepping stone for them to contribute as future nurses to continuous quality improvement processes in workplaces $^{[27,49,63]}$ and to learning organization cultures that embrace life-long learning. ${ }^{[27]}$ It is for this reason that the cyclic interplay between professionhood and professionalism is offered as an educational aid to replicate life-long learning processes.

\subsection{Example of engaging students through course con- tent and process}

In Figure 3, it is shown how the generic template from Figure 2 was tailored to the theme of "values and beliefs that guide the nursing profession in facilitating safe person centred care", which is listed as one of the weekly themes in the course. Examples of documents from nursing organizations (e.g., ICN, CNA, CNO, RNAO, ONA) are listed in Figure 3 section on Professionalism to engage students in the back and forth interplay between student's informed evolving definition of professional nursing with what is expected of nurses by nursing profession. It is in this way that nursing students dialogue about the collective voice of nursing (professionalism) and how it is communicated in a unified manner through international, national, and local nursing organizations.

For example, the International Council of Nurses $(\mathrm{ICN})^{[18]}$ provides general guidance regarding the scope of nursing practice and the values and beliefs that guide nursing practice (e.g., safe person centred practice theme) through ICN code of ethics. ${ }^{[41]}$ However, the ICN guides nurses to consult their
National Nursing Associations (NNAs) in their own country for specific guidance. The $\mathrm{ICN}^{[18]}$ suggests that NNAs bear the responsibility for defining nursing and nurses' roles. The NNA for Canada is the Canadian Nurses Association (CNA). The CNA develops documents that are consistent with ICN principles and then tailors these to fit their nation's health care needs and legislation. ${ }^{[18]}$ Accordingly, guided by $\mathrm{ICN}^{[18]}$ principles for nurse's scope of practice and $\mathrm{ICN}^{[41]}$ code of ethics, the $\mathrm{CNA}^{[42]}$ developed a code of ethics to represent the values and beliefs that guide the nursing profession in Canada.

The $\mathrm{CNA}^{[42]}$ code of ethics is further specified at the provincial level in Ontario through the College of Nurses of Ontario $(\mathrm{CNO})^{[43]}$ practice standard on ethics. The $\mathrm{CNO}$ as the regulatory body outlines seven common values and beliefs that guide nursing practice in Ontario, these are: 1) client [person] well-being; 2) client choice and limits to client choice; 3) privacy and confidentiality; 4) respect for life; 5) maintaining commitments; 6) truthfulness; and 7) fairness. In addition, the $\mathrm{CNO}^{[43]}$ states that these seven ethical values "are shared by society and upheld by law [and]... it is recognized that client well-being and client choice [and limits to client choice] are primary values". As an example, students would engage by selecting one of the $\mathrm{CNO}$ values that stood out for them. Following the prompts on the worksheet in Table 2, this would mean that if a student or a group of students choose to integrate the $\mathrm{CNO}$ value and belief of "client well-being" into their informed evolving definition of professional nursing, students would name theoretical idea (e.g., CNO value of client well-being), define it, support it with the source, and provide a specific example of application. It is in this way that students are invited to create, recreate, and tailor their application of the theoretical idea of client well-being based on the salient features of the case scenarios or case study. Finally, students highlight any new insights (aha moments), in context of specific situations and examples from class discussion and readings. Then the process repeats with each of the other theoretical ideas from course readings.

Continuing with the example of these primary $\mathrm{CNO}$ values of client well-being, client choice, and limits to client choice as representing what is expected of nurses by the profession, these values thread through ICN, CNA, CNO, RNAO, and ONA documents as shown in Figure 3 section on professionalism. For example, the Registered Nurses Association of Ontario (RNAO) provides nurses with evidenced-informed professional support through its nursing best practice guidelines. Guided by RNAO's mandate to advocate for healthy public policy and for the role of registered nurses in serving the public, documents developed by RNAO are enacted in a manner that is consistent with $\mathrm{CNO}$ to facilitate safe 
person centred care. Accordingly, the RNAO incorporates $\mathrm{CNO}{ }^{[43]}$ client centred commitments and ethical values such as client well-being, client choices and limits to client choices within their nursing best practice guidelines (BPG). Some examples are found in the recently revised BPG of: 1) person and family centred care; $;^{[45]}$ and 2) the assessment and management of pain. ${ }^{[61]}$ In addition, within the best practice guideline on facilitating client learning, the RNAO (p.14) ${ }^{[62]}$ formally states that the "ethical values guiding the BPG on the facilitation of client centred learning [are from $\mathrm{CNO}$ and] include: "client well-being; client choice; respect for life; maintaining commitments; truthfulness; and fairness".

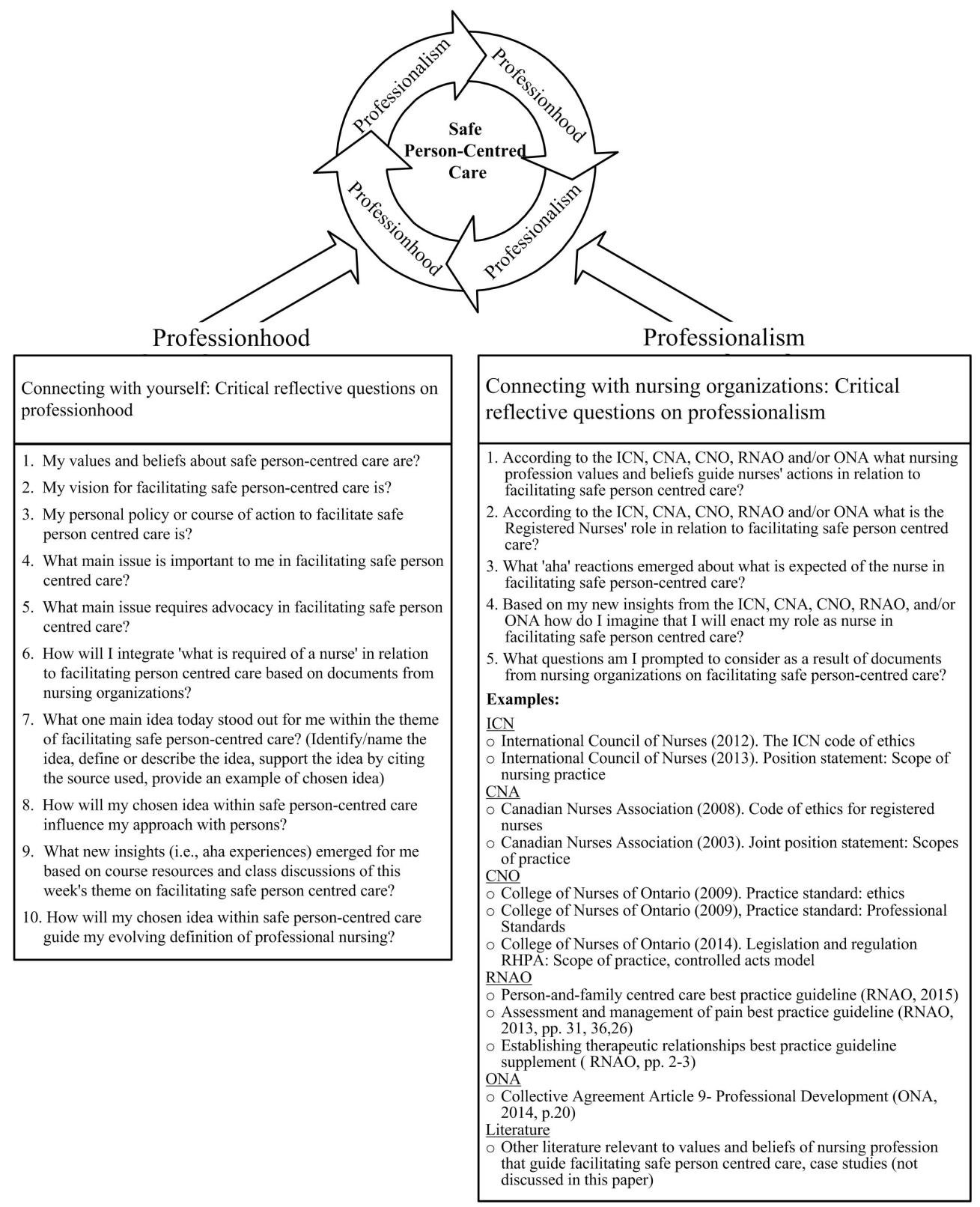

Figure 3. Application of cyclic interplay between professionhood and professionalism to one of the weekly themes of facilitating safe person-centred care

Similarly values that guide safe person centred care is also addressed by ONA and its national affiliate, the Canadian Federation of Nurses' Unions (CTNU). ONA is a union that is primarily concerned with nurse's working conditions. Consistent with $\mathrm{CNO}^{[20]}$ quality assurance requirements, ONA promotes on-going development and education so that nurses can enact their scope of practice in a manner that is safe and person centred. As shown in Figure 3, ONA ${ }^{[34]}$ provides documents such as the collective agreement. Student engage in the development of self and profession by engaging 
individually and as a group with documents developed by ONA. These ONA documents are enacted in a manner that is consistent with CNO standards and practice guidelines. For example, ONA's collective agreement ${ }^{[34]}$ indicates that nurses and employers have a "joint responsibility" in professional development (p.20). Consistent with $\mathrm{CNO}^{[38]}$ and RNAO, ${ }^{[64]}$ ONA prompts nurses and employers to work together to consider what type of professional development is required by nurses. $\mathrm{RNAO}^{[64]}$ suggests that nurses' professional relationships are based on nurses" "self-awareness, self-knowledge... awareness of boundaries and limits of the professional role" all of which are dimensions of developing a professional nursing identity as it relates to facilitating safe person centred care by knowing self (p.8,20). It is in this way that students are invited to engage with the collective voice of nursing (professionalism) as it pertains to what is required of them as communicated through international, national, and local nursing organizations.
The classroom assessment technique of a minute paper ${ }^{[65]}$ was used to assess outcomes of learning. The minute paper was used by stopping the class for five minutes and asking students to anonymously respond briefly to questions such as "What is the most important thing you learned today? What important question remains unanswered? Or what remains least clear to you?" (p.148) ${ }^{[65]}$ The minute paper was used at the beginning or end of class as a warm-up activity or as a wrap-up activity to ensure that students' questions are raised for dialogue. ${ }^{[65]}$ An excerpt of a minute paper is shown in Table 3. While the formal evaluation of student attitudes has not been formally undertaken, the anonymous written course feedback and anecdotal information from students at the end of the course and formatively throughout the course indicated that the pattern of moving back and forth between their informed evolving definition of professional nursing and what is required of them by the nursing profession was helpful in experiencing the process of life-long learning which repeats.

Table 3. Excerpt of minute paper to assess student learning

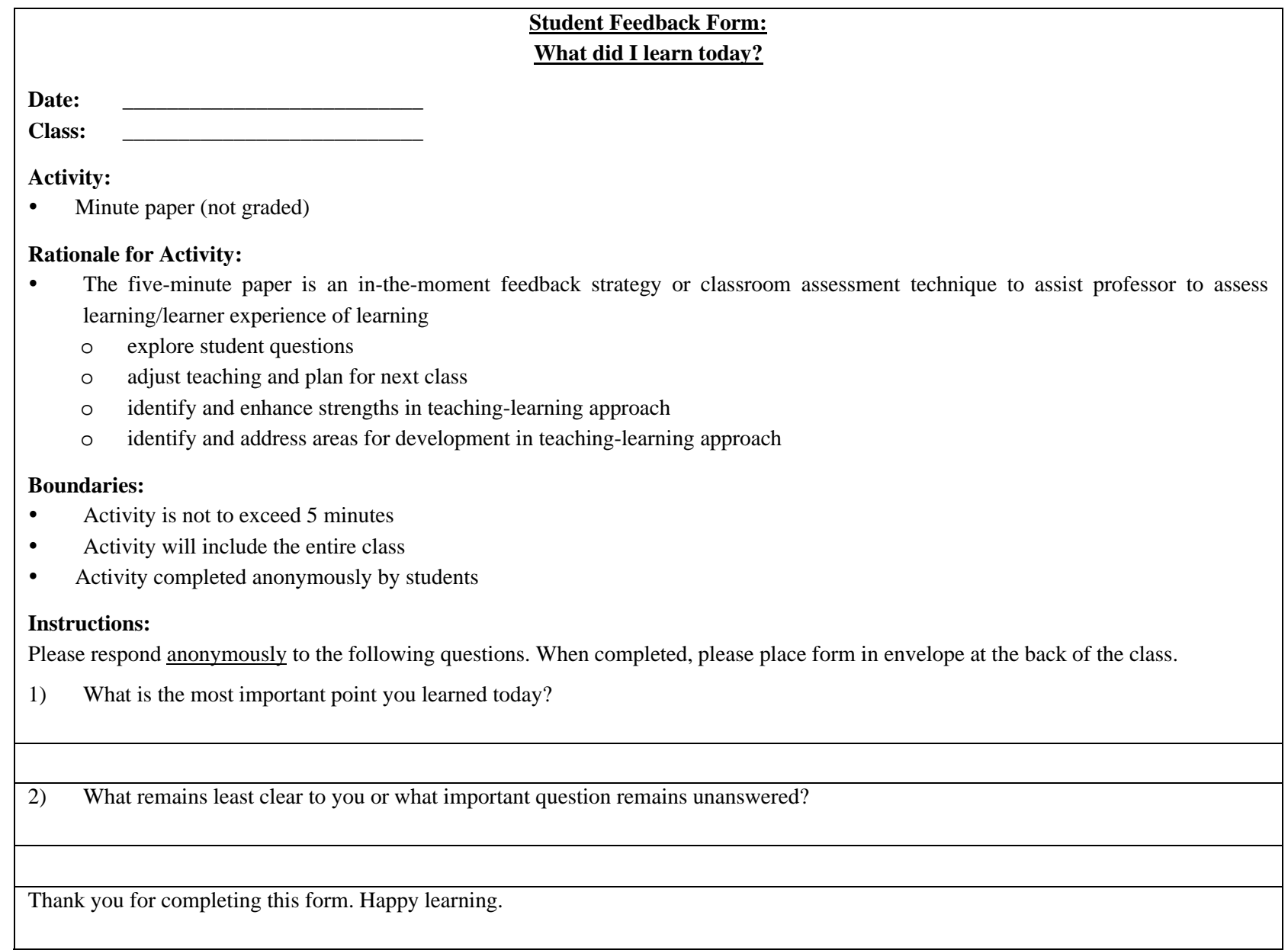




\section{Conclusion}

Using educational aids that replicate the process of life-long learning through the on-going development and renewal of self and profession is important to supporting the education and practice of nursing students. Styles ideas of professionhood and professionalism were used as an educational aid for actively navigating the back and forth interplay between nursing students' own evolving definition of professional nursing and what is required by the nursing profession. As shown through the examples and figures provided, professionhood and professionalism exist together, each informing the other. The cyclic interplay between professionhood and professionalism is a tool or lens for students and educators to continue to develop and affirm their professional nursing identity individually and as a group. Levine, ${ }^{[66]}$ a nursing theorist encourages nurses to celebrate different viewpoints by asserting that each perspective "offers a fresh vision of familiar concepts brought together in bold new designs" (p.14). It is hoped that the cyclic interplay between professionhood and professionalism will facilitate an attitude of on-going development and renewal of self and profession by bringing together individual and collective ideas in bold new designs that will continue to inspire dialogue that informs, affirms, rejuvenates, creates, re-creates, transforms, and/or reflectively questions what is meaningful to nurses based on evolving societal needs.

\section{CONFlicts OF INTEREST Disclosure}

The author declares that there are no competing interests.

\section{REFERENCES}

[1] Fackler C, Chambers A, Bourbonniere M. Hospital nurses lived experiences of power. Journal of Nursing Scholarship. 2015; 47(3): 267-274. PMid: 25690529 http://dx.doi.org/10.1111/jnu.1 2127

[2] Chiovitti RF. Nurses; meaning of caring with patients in acute psychiatric hospital settings: A grounded theory study. International Nursing Studies. 2008; 45(2): 203-223. PMid: 17049355 http://dx.doi.org/10.1016/j.ijnurstu.2006.08.018

[3] Styles MM. Professionalism and professionhood. In: Styles, MM (Eds.). Toward a new endowment. 1st ed. St. Louis USA: Mosby; 1982. 7-9.

[4] Madden-Styles M. Nursing's unspoken word. Florida Nurse. 2006; 54(2): 19-20. Available from: http://search.proquest.com/ docview/230321906? accountid=11530

[5] Chiovitti RF. Theory of protective empowering for balancing patient safety and choices. Nursing Ethics. 2011; 18(3): 213-220. http://dx.doi.org/10.1177/0969733010386169

[6] Canadian Nurses Association. Position statement: Evidenceinformed decision-making and nursing practice. Ottawa: 2010. Available from: http://www.cna-aiic.ca/ /media/cna/pa ge-content/pdf-en/ps113_evidence_informed_2010_e.p df?la=en

[7] Chiovitti RF, Gallop R. Detecting nurse perceived treatment difficulty of psychiatric patients in hospital: Evaluation of a patient assessment sheet. Journal of Psychiatric and Mental Health Nursing. 2000; 7(3): 213-220. PMid: 11249314 http://dx.doi.org/10.1046/j.136 5-2850.2000.00285.x

[8] DiCenso A, Cullum N, Ciliska D. Implementing evidence-based nursing: Some misconceptions. Evidenced-Based Nursing. 1998; 1(2): 38-40. http://dx.doi.org/10.1136/ebn.1.2.38

[9] Rush J, Fiorino-Chiovitti RF, Kaufman k, et al. A random trial of a nursery ritual: Wearing cover gowns to care for healthy newborns. Birth. 1990; 17(1): 25-30. PMid: 2189428 http://dx.doi .org/1 $0.1111 / j .1523-536 \mathrm{X} .1990$. tb00006.x

[10] Lemire RG. Canadian Nurses Association. In: McIntyre M, Thomlinson E, McDonald C (eds.) Realities of Canadian Nursing: Professional, Practice, and Power Issues. 2nd ed. Philadelphia, USA: Lippincott Williams \& Wilkins; 2006. 133-151.
[11] Krautscheid L. Defining professional nursing accountability: A literature review. Journal of Professional Nursing. 2014; 30(1): 43 47. PMid: 24503314 http://dx.doi.org/10.1016/j.profnur s.2013.06.008

[12] Samuel M, Chiche S. The power of personal accountability. New York USA. Xephor Press; 2004.

[13] Raffin BS, Ecker M. Nursing values and ethics. In: Potter P, Perry A, Ross-Kerr J, Wood M, Astle B, Duggleby W (Eds.) Canadian fundamentals of nursing. 5th ed. Toronto Canada: Elsevier; 2014. 80-93.

[14] College of Nurses of Ontario [CNO]. Introduction: Developing practice standards and guidelines (Publication 41046). Toronto Canada; 2009. Available from: http://www.cno.org/Global/docs/pr ac/41046_fsDevelopingstds.pdf

[15] Canadian Nurses Association. Framework for the practice of registered nurses in Canada. Available from: https://www.cna-aiic.ca/ /media/cna/page-conte $\mathrm{nt} / \mathrm{pdf}$-en/framework-for-the-pracice-of-registere d-nurses-in-canada.pdf?la=en

[16] Schiller C. Self-regulation of the nursing profession: A focus on four Canadian provinces. Journal of Nursing Education and Practice. 2015; 5(1): 95-106. http://dx.doi.org/10.5430/jnep.v5n1p95

[17] College of Nurses of Ontario [CNO]. Competencies for entry-level Registered Nurse practice (Publication 41037). Toronto Canada. 2014. Available from: http://www.cno.org/Global/docs/reg/4103 7_EntryToPracitic_final.pdf

[18] International Council of Nurses [ICN]. Position statement: Scope of nursing practice. Author, Geneva, Switzerland. 2013 Available from: http://www.icn.ch/images/stories/documents/pu blications/position_statements/B07_Scope_Nsg_Pract ice.pdf

[19] College of Nurses of Ontario [CNO]. Practice standard: Medication (Publication 41007). Toronto Canada. 2015. Available from: http: //www.cno.org/Global/docs/prac/41007_Medication.pdf

[20] College of Nurses of Ontario [CNO]. Quality assurance: Practice assessment guide (Publication 44046). Toronto Canada. 2015. Available from: http://www.cno.org/Global/docs/qa/44046 _QA2015PracAssessGuide.pdf 
[21] Rolfe G. Rethinking reflective education: What would Dewy have done? Nurse Education Today. 2014; 34(8): 1179-1183. http: $/ /$ dx.doi.org/10.1016/j.nedt.2014.03.006

[22] Dube V, Ducharme F. Nursing reflective practice: An empirical literature review. Journal of Nursing Education and Practice. 2015; 5(7): 91. http://dx.doi.org/10.5430/jnep.v5n7p91

[23] Jarvis P. Lifelong education and its relevance to nursing. Nurse Education Today. 2005; 25(8): 655-660. PMid:16290158 http: $/ /$ dx.doi.org/10.1016/j.nedt.2005.09.005

[24] Schon D. Educating the reflective practitioner: Toward a new design for teaching and learning in the professions. 1st ed. San Francisco USA. Jossey-Bass; 1987.

[25] Kolb DA. Experiential learning: Experience as the source of learning and development. Englewood Cliffs, N.J. Prentice-Hall; 1984.

[26] Dewey J. Experience and nature. Chicago. Open Court Pub. Co. 1925.

[27] Senge PM. The fifth discipline: The art and practice of the learning organization. New York. Doubleday/Currency; 2006.

[28] Shields E. Reflection and learning in student nurses. Nurse Education Today. 1995; 15(6): 452-458. http://dx.doi.org/10.1016/S02 60-6917 (95) 80058-1

[29] Burrows D. The nurse teacher's role in the promotion of reflective practice. Nurse Education Today. 1995; 15(5): 346-350. http: //dx.doi.org/10.1016/S0260-6917 (95)80007-7

[30] Pettigrew AC. Learning and students. In: Oermann MH (Eds.). Teaching in nursing and role of the educator: The complete guide to best practice in teaching, evaluation, and curriculum development. 1st edition. New York USA: Springer Publishing Company; 2015. 15-34.

[31] College of Nurses of Ontario [CNO]. Legislation and regulation RHPA [Regulated Health Professions Act and Nursing Act]: Scope of practice, controlled acts model (Publication 41052). Toronto Canada. 2014. Available from: http://www.cno.org/Global/docs/po licy/41052_RHPAscope.pdf

[32] Mosby's dictionary of medicine, nursing, \& health professions. 8th ed. St. Louis: Mosby Elsevier; 2009. 57.

[33] Registered Nurses' Association of Ontario [RNAO]. Professionalism in nursing: Healthy work environments best practice guidelines. Author, Toronto Canada. 2007. Available from: http://rnao.ca/si tes/rnao-ca/files/Professionalism_in_Nursing.pdf

[34] Ontario Nurses Association. Collective agreement [expiry March 31, 2016]. Toronto. ONA; 2014. Available from: https: //www.ona.org/documents/File/pdf/cas/hospitals/Hos pitalCentralAgreement-English_March312016.pdf

[35] Oxford Canadian dictionary. 2nd ed. Don Mills, Ontario: Oxford University Press; 2006. 803.

[36] Benner P, Sutphen M, Leonard V, et al. Developing clinical imagination. In: Benner P, Sutphen M, Leonard V \& Day L (eds.) Educating nurses: A call for radical transformation. 1st ed. United States of America: Jossey-Bass; 2010. 143-154.

[37] College of Nurses of Ontario. Practice standard for infection prevention and control (Publication 41002). Toronto Canada. CNO; 2009. Available from: http://www.cno.org/Global/docs/prac/410 02_infection.pdf

[38] College of Nurses of Ontario [CNO]. Competencies for entry-level Registered Nurse practice (Publication 41037). Toronto Canada. 2014. Available from: http://www.cno.org/Global/docs/reg/4103 7_EntryToPracitic_final.pdf

[39] Styles.MM. Regulation and profession building: A personal perspective. International Nursing Review. 2005; 52(2): 81-82. PMid:15842314 http://dx.doi.org/10.1111/j.1466-7657. 2005.00436.x

[40] Allen D. What do you do at work? Profession building and doing nursing. International Nursing Review. 2007; 54(1): 41-48.
PMid: 17305956 http://dx.doi.org/10.1111/j.1466-7657. 2007.00496.x

[41] International Council of Nurses [ICN]. The ICN code of ethics for nurses. Author, Geneva, Switzerland. 2012. Available from: http://www.icn.ch/images/stories/documents/ab out/icncode_english.pdf

[42] Canadian Nurses Association. Code of ethics. Centennial edition. Ottawa. Author. 2008. Available from: http: //www.cna-aiic.ca/ /media/cna/page-content/pdf -fr/code-of-ethics-for-registered-nurses.pdf?la=en

[43] College of Nurses of Ontario [CNO]. Practice standard: Ethics (Publication 41034). Toronto Canada. 2009. Available from: http: //www.cno.org/Global/docs/prac/41034_Ethics.pdf

[44] Ontario Nurses Association. ONA: Mission, vision, objectives, philosophy, and history. Toronto. ONA; n.d. Available from: http: //www. ona.org/mission.html

[45] Registered Nurses' Association of Ontario [RNAO]. Person-and family-centred care: Nursing best practice guideline. Author, Toronto Canada. 2015. Available from: http://rnao.ca/sites/rnao-c a/files/FINAL_Web_Version_1.pdf

[46] Clarke H. Health and nursing policy: a matter of politics, power, and professionalism. In: McIntyre M, McDonald C (eds.) Realities of Canadian nursing: Professional, practice and power issues. 3rd ed. Philadelphia USA: Lippincott Williams \& Wilkins; 2010. 68-90.

[47] Storch E. Canadian health care system. In: McIntyre M, McDonald C (Eds.). Realities of Canadian nursing: Professional, practice, and power issues. 3rd ed. Philadelphia USA: Lippincott, Williams, \& Wilkins; 2010. 34-55.

[48] Romanow RJ. Building on values: The Future of Health Care in Canada. Commission on the Future of Health Care in Canada, Saskatoon. 2002. Available from: http://www.hc-sc.gc.ca/hcs-sss /alt_formats/hpb-dgps/pdf/hhr/romanow_e.pdf

[49] Deming W, Cornesky RW. Edwards Deming: Improving quality in colleges and universities. 1st ed. United States of America. Magna Publications; 1990.

[50] Fox D. Personal theories of teaching. Studies in Higher Education. 2015; 8(2): 151-163. http://dx.doi.org/10.1080/030750783 12331379014

[51] Gibbs J, Schnell S. Moral development versus socialization: A critique. American Psychologist. 1985; 40(10): 1071-1080. http: //dx.doi.org/10.1037/0003-066X.40.10.1071

[52] Crigger N, Goffrey N. From the inside out: A new approach to teaching professional identity formation and professional ethics. Journal of Professional Nursing. 2014; 30(5): 376-382. PMid:25223285 http://dx.doi.org/10.1016/j.profnurs.2014.03.004

[53] Pascarella E. Student's affective development within college environment. Journal of Higher Education. 1985; 56(6): 640-663. http://dx.doi.org/10.2307/1981072

[54] Lave J, Wenger E. Situated learning: Legitimate peripheral participation. England: Cambridge University Press; 1991. http: //dx.doi.org/10.1017/CB09780511815355

[55] Gage N. The paradigm wars and their aftermath: A historical sketch of research on teaching since 1989. Educational Researcher. 1989; 18(7): 4-10.

[56] Palmer P. Good teaching: A matter of living the mystery. Change: The magazine of higher learning. 1990; 22(1): 11-16. http://dx.d oi.org/10.1080/00091383.1990.9937613

[57] Watson J. Transformative thinking and a caring curriculum. In: Bevis EO, Watson J (Eds.). Toward a caring curriculum: A new pedagogy for nursing. Sudbury: Jones and Bartlett Publishers; 2000. 51-60. 
[58] Cochran-Smith M, Lytle S. Research on teaching and teacher research: The issues that divide. Educational Researcher. 1990; 19(2): 2-11. http://dx.doi.org/10.3102/0013189x019002002

[59] Walker 1, Clendon J, Walton J. What nurses think about professionalism: What it means to be "professional"? Kai Tiaki Nursing New Zealand. 2015; 21(1): 12-13.

[60] Burton AJ. Reflection: Nursing practice and education pancreas? Journal of Advanced Nursing. 2000; 31(5): 1009-1017. PMid: 10840233 http://dx.doi.org/10.1046/j.1365-2648. 2000.01395.x

[61] Registered Nurses' Association of Ontario [RNAO]. Assessment \& management of pain: Clinical best practice guideline (3rd edition). Toronto Canada; 2013. Available from: http://rnao.ca/sites/rnao-ca/files/AssessAndManag ementOfPain_15_WEB-_FINAL_DEC_2.pdf

[62] Registered Nurses' Association of Ontario [RNAO]. Facilitating client-centred learning: Nursing best practice guideline. Toronto
Canada. 2012. Available from: http://rnao.ca/sites/rnao-c a/files/BPG_CCL_2012_FA.pdf

[63] Berwick D. Preparing nurses for participation in and leadership of continual improvement. Journal of Nursing Education. 2011; 50(6): 322-327. PMid:21634326 http://dx.doi.org/10.3928/01484 834-20110519-05

[64] Registered Nurses Association of Ontario [RNAO]. Establishing therapeutic relationships: Nursing best practice guideline. Author, Toronto Canada; 2002. Available from: http://rnao.ca/sites/rnao-ca/files/Establishing_T herapeutic_Relationships.pdf

[65] Angelo T, Cross, K. Classroom assessment techniques: A handbook for college teachers (2nd edition). USA: Jossey-Bass 1993.

[66] Levine M. The rhetoric of nursing theory. Journal of Nursing Scholarship. 1995; 27(1): 11-14. http://dx.doi.org/10.1111/j.154 7-5069.1995.tb00807.x 